Meta

Journal des traducteurs

Translators' Journal

\title{
What's so Special about Legal Translation?
}

\section{Malcolm Harvey}

Volume 47, numéro 2, juin 2002

Traduction et terminologie juridiques

URI : https://id.erudit.org/iderudit/008007ar

DOI : https://doi.org/10.7202/008007ar

Aller au sommaire du numéro

Éditeur(s)

Les Presses de l'Université de Montréal

ISSN

0026-0452 (imprimé)

1492-1421 (numérique)

Découvrir la revue

Citer cet article

Harvey, M. (2002). What's so Special about Legal Translation? Meta, 47(2),

177-185. https://doi.org/10.7202/008007ar

\section{Résumé de l'article}

Cette étude vise à passer en revue les principales difficultés de la traduction juridique, en se demandant si elles en font, comme d'aucuns le prétendent, une catégorie à part. Elle propose une définition relativement large de la traduction juridique, ce qui conduit à nuancer ses prétendues spécificités.
Ce document est protégé par la loi sur le droit d'auteur. L'utilisation des services d’Érudit (y compris la reproduction) est assujettie à sa politique d'utilisation que vous pouvez consulter en ligne.

https://apropos.erudit.org/fr/usagers/politique-dutilisation/ 


\title{
What's so Special about Legal Translation?
}

\author{
MALCOLM HARVEY \\ Université Lumière Lyon 2, Lyon, France
}

\begin{abstract}
RÉSUMÉ
Cette étude vise à passer en revue les principales difficultés de la traduction juridique, en se demandant si elles en font, comme d'aucuns le prétendent, une catégorie à part. Elle propose une définition relativement large de la traduction juridique, ce qui conduit à nuancer ses prétendues spécificités.
\end{abstract}

\section{ABSTRACT}

The aim of this paper is to provide an overview of the main difficulties of legal translation and discuss whether they justify claims that it is a category in its own right. It proposes a wide-ranging definition of legal translation, which calls into question some received notions about its inherent difficulties.

\section{MOTS-CLÉS/KEYWORDS}

ambiguity, difficulties of legal translation, fidelity in translation, legal documents

Bold claims have been made about legal translation. It has been described as a category in its own right (Weston 1991: 2, Gémar 1995b: 143-154, Garzone 2000: 395) and as "the ultimate linguistic challenge," combining the inventiveness of literary translation with the terminological precision of technical translation (Cairns \& McKeon 1995: 191, cf. Gémar 1995a: 9, Pelage 2000: 127).

Claims to special status for legal translation are based on at least two debatable assumptions. The first is the notion that a sliding scale of difficulty can be established between different translation genres. Depending on the experience of the translator and the nature of the task in hand, each new assignment involves a combination of old routines and new challenges. It might be added that categories such as "scientific translation" and "literary translation" are not watertight. Literary texts, in common with other text types, are a hybrid form: for instance, knowledge of the law would not come amiss when translating the novels of P. D. James or John Grisham.

The second unsafe premise is a somewhat idealistic view of the epistemology of scientific subjects, often thought by non-scientists to be unproblematic. As Joseph remarks, "it is not unusual for specialists in a particular discipline to believe that other disciplines are better founded, less subject to skeptical doubts and speculative changes than their own" (1995: 15, cf. Gémar 1995a: 119).

It could be added, with just a dash of cynicism, that ambitious claims for a particular activity may be underpinned by socio-professional considerations: if legal translation requires more time and/or skill than other types of assignment, then it follows that legal translators should be paid more. 


\section{When is a document a legal document?}

General statements about legal translation are necessarily determined by the writer's definition of a legal document. Sarcevic (1997: 9) defines legal language as specialpurpose communication between specialists, thereby excluding communication between lawyers and non-lawyers. This restriction disqualifies several text types which make up a large part of the translator's workload: contracts, judgements, correspondence with lawyers and legal authorities, etc. Indeed, one of the hallmarks of legal discourse is arguably that it is not restricted to specialists, but is (at least in theory) intended for the lay citizen. ${ }^{1}$ In some cases the lawyer acts as an intermediary or surrogate addressee, ${ }^{2}$ "translating" the word of the law into everyday language (cf. Cornu 1990: 23); in others the layperson becomes a substitute lawyer (e.g. as juror or lay justice) and makes utterances having legal effects (wills, the verdict of "Guilty/not guilty" or the words "I do" during a wedding ceremony).

This complex communicative situation, which is almost unique in special-purpose communication, ${ }^{3}$ may explain why the language of law, along with medicine, has been lampooned over the centuries by authors ranging from Molière to Swift and, more recently, the Plain English campaign. Such demands are rarely placed on other subject areas: people rarely complain that they cannot understand the language of nuclear physicists or biochemists. The ambitious adage "Ignorance of the law is no excuse/Nul n'est censé ignorer la loi” has no equivalent in most special-purpose languages, which are generally restricted to communication among specialists (Sarcevic 1997: 55, Sager 1980: 68-9). ${ }^{4}$

A narrow definition of legal language also leads scholars to identify supposed characteristics which are open to question. For instance, it is stated that authorlessness is a feature of legal language (Sourioux \& Lerat 1975: 44-46), in particular statutes (Cornu 1990: 279-82), and that this has consequences for the status of the legal translator (Joseph 1995: 19-21). However, there are cases of documents dealing with the law, or even stating the law, in which the first-person singular is prominent: for instance, wills, notary's documents in French, and the judicial opinions of the House of Lords (Harvey 1997: 269-274).

Similarly, Sarcevic (1997) focusses on parallel texts of statutory instruments, treaties and judicial opinions. The claim that "unlike other areas of special-purpose translation, the main goal of legal translators cannot be to produce a text with the same meaning as the message of the source text" (Sarcevic 1997: 70) is valid for parallel texts, which are intended to produce equal legal effects, but is difficult to apply to more everyday tasks such as translating police documents for refugees or witness statements by foreign-language speakers.

A more inclusive definition of what constitutes a legal text would cover documents which are, or may become, part of the judicial process: for instance, contracts, wills, court documents, witness statements and expert reports, which are "bread and butter" activities for lawyers and legal translators. ${ }^{5}$ This definition includes not just the word of the law but also the word of the participant in the legal process; ${ }^{6}$ by embracing both authoritative and non-authoritative statements, it may shed a different light on the supposed special status of legal translation. In particular, the fact that scholarly work on legal translation tends to focus on the translation of statutes, reflecting the "legicentrism" of legal scholarship in general (Kasirer 2000: 65), partly accounts 
for the traditional reverence for the source text (see section 2.3), which is not necessarily appropriate when translating other forms of legal discourse.

\section{Characteristics of legal translation}

\subsection{The nature of legal discourse}

Several authors claim that the special status of legal translation derives from the prescriptive nature of legal discourse, which gives rise to legal effects (Koutsivitis 1988: 44-50, Gémar 1995b: 144-5). Sarcevic (1997: 11) divides legal documents into prescriptive and descriptive texts, plus hybrid texts which contain both functions (e.g. judicial decisions, appeals, petitions). Texts with a primarily expressive function are excluded from this definition.

Several questions arise from this. First, it is something of a tautology to say that legal translation is unlike other forms of translation because the target text has legal effects: by their very nature, non-legal texts cannot have legal effects. If this definition is extended to saying that the target text must have effects in the special subject area, then this is true of all special-purpose texts: texts on astrophysics must have effects for astrophysicists, etc.

Secondly, in focussing on prescriptive documents, there is a risk of overlooking the expressive or persuasive function which inevitably occurs in a form of discourse founded on rhetoric. True, this function arises mainly in communication between lawyer and layperson (e.g. counsel addressing a jury), which some theorists would not define as legal discourse. However, there are also examples of persuasive communication between lawyers, e.g. the explanatory parts of a judicial decision, or a scholarly article explaining why a change is needed (or was misguided). ${ }^{7}$ In such cases, the aim is not to prescribe or describe but to convince, a common function in professional communication (Gile 1995: 25-26).

Finally, the prescriptive function is not absent from other special-subject areas: the advice contained in an instructions manual is prescriptive once readers have "entered the pact," symbolised by breaking the seal, if they want the instrument to perform its intended task. Directions for use of medical equipment, or indeed a household implement, are in practice both descriptive and prescriptive.

The function of a document depends not on its inherent nature but on the communicative situation. A statute is prescriptive in the eyes of the citizen compelled to abide by $i^{8}$ but is merely informative to the person with a potential interest in it (e.g. a person researching company law with a view to setting up a business). Similarly, a contract is binding on the parties involved, but simply a source of information to a third-party observer consulting it for future use. In legal as in other forms of communication, pragmatic considerations are the most reliable way of determining function.

\subsection{A system-bound discipline}

One of the most striking epistemological features of law is its lack of a common knowledge base or "universal operative referents" (référents opératoires universels, Pelage 2000: 127) such as the laws of mathematics. It is an amalgam of different systems 
which have evolved separately and are generally confined within national and linguistic boundaries (Groffier 1990: 314). For the legal translator, this results in the problem of finding equivalents for culture-bound terms, particularly those related to concepts, procedures, institutions and personnel (Weston 1991, Harvey 2000). This systemic diversity is another argument for the special status of legal translation (Gémar 1979: 44-48).

Law is certainly unusual in being system-bound but is not unique in this respect: religion and political science, which are historically related to law, are inseparable from the notion of systems. Nor are culture-bound concepts specific to the field of law: they permeate literary texts ${ }^{9}$ and indeed crop up in all fields of knowledge which have not been completely standardised. ${ }^{10}$ Given the increasing importance of European and international law, it can be anticipated that the law will gradually become more standardised.

\subsection{Fidelity}

The debate over fidelity to the "letter" or the "spirit" in legal translation is a longstanding one, dating back to the days of the Roman empire when it was decreed that formal correspondence between source and target text was essential to preserve the meaning of both Biblical ${ }^{11}$ and legal documents (Gémar 1995a: 26-30, Sarcevic 1997: 23-48). This was underpinned by belief in the magical properties of the logos: if the wording was changed, the incantatory force might be lost. In monolingual legal drafting, this was reflected in the insistence on meticulous wording in writs, failing which they were declared invalid (Mellinkoff 1963: 113-4). Similarly, translators were instructed to adhere scrupulously to the original text, a tendency which lasted until the twentieth century when the rise in national language consciousness in bi- or multilingual countries such as Switzerland, Belgium and Canada resulted in greater respect for the "genius" of the target language (Sarcevic 1997: 34-53; Gémar 1995b: 7-28).

The current definition of fidelity in translation has been greatly refined (Gile 1995: 49-74). Kasirer (2000: 66-67) argues that the letter versus spirit debate is unhelpful, since both options relegate the translator to the role of a passive mediator: "the notion that a legal text has a spirit tends to be understood as a signal that it has a single, fixed meaning fixed by the author, over which meaning the interpreter or translator has no control." Specialists in legal translation now define fidelity as achieving an equivalent impact on the target reader, which may justify substantial changes to the original text to respect the stylistic conventions of the target legal culture (Sparer 1979: 78-90, Covacs 1982: 95). Authors influenced by German-speaking theorists, notably Vermeer's Skopos theory which involves fidelity not to the meaning of the source text but to the function of the target text, call for target-oriented legal translation adopting a functionalist approach (Garzone 2000). The translator thus becomes a "text producer" rather than a "bilingual typist" providing simple linguistic equivalence (Hammond 1995: 238-9).

Taking this idea further, Sarcevic proposes a redefinition of legal translation, measuring success in terms not of formal correspondence between source and target text but of equivalent legal effects, in particular when the text is construed by the courts (1997: 71). In the case of parallel drafting, where there is no original text to 
translate but an original intent to render in several languages, the notion of fidelity is stretched even further: "the translator's first consideration is no longer fidelity to the source text but rather fidelity to the uniform intent of the single instrument, i.e. what the legislator or negotiators intended to say" (Sarcevic 1997: 112, author's emphasis). This approach is also adopted by Canadian jurilinguists, since the equal status of the English and French versions of statutes makes formal parallelism unnecessary (Sparer 1988: 325).

As regards fidelity, legal translation has thus been brought into line with other forms of translation. And yet, despite these advances by both scholars and practitioners, linguistic fidelity is still frequently required of legal translators (cf. GawronZaborska 2000, Kasirer 2000: 57). For instance, the UN Instructions for translators stipulate that "fidelity to the original text must be the first consideration" (quoted by Sarcevic 1997: 16). Similarly, translators working in the US are advised not to alter the length of sentences to avoid imposing their own interpretation (Beyer \& Conradsen 1995: 164). ${ }^{12}$ This literal view of fidelity reflects the positivist tradition in legal interpretation, which holds that the meaning of a legislative text is "declared," rather than being construed or created, by the person interpreting it (Kasirer 2000: 57-59). A similarly narrow view of fidelity is apparently still encountered by court interpreters (Morris 1995: 266). Since lawyers are well aware of the empowering nature of language, they are evidently reluctant to grant translators leave to use the words they choose. ${ }^{13}$

\subsection{Ambiguity and interpretation}

Another hallmark of law is that language is both the object studied and the means of analysis (Legault 1979: 20). ${ }^{14}$ For the lawyer, language is not simply a medium but the "raw material" to be worked on. Law belongs to the same category of knowledge as politics, ethics and metaphysics, which exist within the realm of rhetoric: their reliance on natural language causes them to be "rotten with ambiguity" (Raymond 2000: 313-7). Whereas most special-purpose communication is based on empirical knowledge and consequently aims at univocity, ambiguity can be deliberate in legal documents. In a contract, it can be used to reach a compromise (Doonan 1995: 95-6) or to create uncertainties which one of the parties will subsequently seek to exploit (Cornu 1990: 90). In the case of international treaties, ambiguity can be a diplomatic tactic (Gémar 1979: 47). The legal text is in this respect comparable to the literary text, in which ambiguity is viewed not a defect but as an inherent feature which should be retained in translation (Posner 1988: 240-2, Jolicœur 2000).

The problem of translating ambiguity leads to the question of interpretation. Again, legal discourse is unusual in that disputes over interpretation are settled by an official body (in this case, a court) which imposes a legally binding construction of a text. ${ }^{15}$ Legal communication thus oscillates between opposing poles: on the one hand, an affinity for ambiguity, on the other hand, the fiction of univocal interpretation $^{16}$ which can discover the true intention of the legislator (the notion of authorial intent, long derided as the "intentional fallacy" by literary critics, is alive and well in both translation studies and legal studies).

This puts the legal translator in a sensitive position. If decoding a text is problematic for a lawyer, it is even more so for the translator. It is generally emphasised 
that the translator must avoid "interpreting" ambiguities since this is a task for trained lawyers (Lane 1982: 223, Beyer \& Conradsen 1995: 153). This is reflected in the above-mentioned insistence on literal translation. It can be retorted that translation, like any act of reading, necessarily involves interpretation (Gémar 1995a: 143, Kasirer 2000: 75) and that placing restrictions on this process prevents the translator from producing quality work (Gawron-Zaborska 2000: 354). Gémar goes as far to suggest that legal translators should first and foremost be trained to interpret texts (1995b: 154), a position opposed by Sarcevic (1997: 91-2).

And yet, if legal translators are truly "text producers" engaged in a dynamic relationship with both sender and receiver, they will inevitably have to tackle questions of interpretation. ${ }^{17}$ Perhaps lawyers need to be persuaded that interpretation is part of creative translation: this would free legal translators of the shackles of literal translation once and for all. If translators have a solid grounding in law and interact with both sender and receiver, they should be equipped to interpret the text as producer/ receivers (the final word rests naturally with the judge). ${ }^{18}$ This proactive role is not incompatible with the technique of deliberate ambiguity: indeed, it requires interpretation to identify ambiguity, decide it is deliberate, and choose to retain it in the translation.

\section{Conclusion}

From the epistemological standpoint, legal translation stands at the crossroads of three areas of inquiry-legal theory, language theory and translation theory-that are fundamentally indeterminate, largely because of their reliance on natural language (Joseph 1995: 14). Law is a notoriously unstable discipline: it cannot be broken down into a table of clearly defined basic elements, but instead relies on fuzzy notions such as "reasonable doubt" and "due process" (Mellinkoff 1963: 20-22). As a result, legal discourse is in a state of constant flux: its meaning shifts depending on the language in which it is expressed and even depending on the reader (David 1982, Gémar 1995b: 130-131). For the translation theorist, this makes legal translation both fascinating and ultimately elusive.

In addition, law is resolutely interdisciplinary, reflecting the fact that it regulates most areas of human activity (Gémar 1979: 51-53, Pelage 2000: 128). Consequently, the legal translator is required to master the basic concepts and terminology of not just law, but also the area to which it is being applied. Interdisciplinarity is not unique to law-information technology and statistics are also used by numerous unrelated disciplines-but is particularly characteristic of it.

However, this brief overview suggests that it is difficult to pinpoint particular features which in practice make legal translation substantially different from other types of special-purpose translation. Most of the difficulties mentioned are not restricted to the field of law or are predicated to a restrictive definition of what constitutes a legal document: for instance, a broader definition of legal texts, argued for above, allows for a more "liberal" approach to the question of fidelity (see 2.3). If legal translation is unusually challenging, this can be attributed not to one particular aspect but rather to the cumulative effect of the various difficulties mentioned.

This paper has also attempted to show that the somewhat daunting claims about legal translation apply mainly to high-level tasks. To be sure, the translation of inter- 
national treaties or multilingual statutory instruments should be left to expert practitioners, but this is only part of the picture. There are numerous other types of legal translation which, with training and practice, can be the subject of challenging but relatively torture-free employment.

\section{Questions}

Should the term "legal translation" be used only for texts having legal effects? Is legal translation restricted to communication between lawyers, or does the term cover documents intended for lapersons?

Are there features of legal translation which make it a category in its own right? Are there instances where fidelity in legal translation imposes literal linguistic equivalence?

Are legal translators justified in explaining ambiguities in the original text if they consider them to be unintentional?

\section{NOTES}

1. Mellinkoff (1963: 18) divides the language of the law into "language that is intended to speak to lawyers and laymen" and argot, "a professional language."

2. Sarcevic (1997: 57-61) refers to "direct" addressees (i.e. lawyers) and "indirect" addressees (i.e. the general public).

3. Medicine is another example of a language which can have a dual addressee, with the general practitioner acting as an intermediary between the specialist and the patient. However, the patient is not empowered with the language of medicine, which is often concealed from him ("doctor knows best").

4. Sager does however acknowledge the role of the "communication mediator" (1980: XIX).

5. This approach is adopted in Morris (1995). Pelage (2000: 126) points out that law as a discipline involves not just norms but reflections on these norms (history of law, jurisprudence, learned opinion etc). Such discourse may be termed "metalegal."

6. Cf. Cornu (1990: 23): "Le langage du droit a vocation à régner non seulement sur les échanges entre initiés, mais dans la communication du droit à tous ceux qui en sont les sujets."

7. For instance, a learned article on the abolition of the chambre d'instruction contains emotional terms such as concept bâtard, exécrable (2000: 2061) and rhetorical flourishes worthy of a lawyer addressing a jury: "La déchéance est indéniable: la chambre a perdu son nom, sa raison d'être et la source de sa puissance. Elle est décapitée" (Jeandidier: 2064).

8. However, given the complexity of modern legislation, its initial function is also in many instances informative (e.g. tax or company law). The prescriptive function, enforced by the judge, comes later.

9. Cf. Posner (1988: 236): "in reading the literature of another culture one cannot divest oneself of one's own cultural identity; understanding, like translation, is mediation, not just reconstruction."

10. Cross-cultural aspects have been noted even in the translation of texts on computing (LavaultOlléon, forthcoming).

11. A number of expressions from the King James Bible (1611), which are now part of everyday language, were in fact originally literal translations of the Hebrew: by the skin of one's teeth, the salt of the earth, to take the words from someone's mouth, the powers-that-be, etc.

12. Sparer (1979: 87) gives the opposite advice in the bilingual context of Canada.

13. Lawyers themselves do not necessarily adhere to the letter of the law: for instance, article 1156 of the French Code civil instructs judges interpreting a contract to look for the underlying intention of the parties, not the literal meaning of the words.

14. It is not unique in this respect: language has the same dual function in philosophy and linguistics, and often in literature.

15. Another example of official interpretation, and indeed one of the oldest academic disciplines, is the exegesis of religious texts.

16. Judges, like Humpty-Dumpty, create the illusion that words mean exactly what they want them to say, since they are free to define terms as they see fit. 
17. The term "interpretation" is used here in the everyday, non-legal sense. On the differences between the interpretation of literary and legal texts, particularly with regard to intentionalism, see Posner (1988: 209-268).

18. As Gémar (1995b: 166) puts it, the role of judges is "dire le droit" whereas the role of translators is "dire le texte."

\section{REFERENCES}

Asтті/Еті (2000): La traduction juridique: histoire, théorie(s) et pratique, Bern/Genève, ASTTI/ ETI.

Beyer, V. \& K. Conradsen (1995): “Translating Japanese Legal documents into English: A Short Course," in M. MORRIs (1995), pp. 145-177.

Cairns, W. \& R. McKeon (1995): Introduction to French Law, London, Cavendish.

Cornu, G. (1990): Linguistique juridique, Paris, Montchrestien.

Covacs, A. (1982): "La réalisation de la version française des lois fédérales du Canada," in J.-C. GÉmAr (1982), pp. 83-100.

David, A. (1982): “Les termes élémentaires du droit," in J.C. GÉmar (1982), pp. 31-38.

Doonan, E. (1995): Drafting, London, Cavendish Publishing.

Garzone, G. (2000): "Legal Translation and Functionalist Approaches: a Contradiction in Terms?," in ASTTI/ETI (2000), pp. 395-414.

Gawron-Zaborska, M. (2000): "Le fantôme de la traduction littérale dans la traduction juridique," in ASTTI/ETI (2000), pp. 349-356.

GÉmAR, J.-C. (1979): "La traduction juridique et son enseignement: aspects théoriques et pratiques," Meta, 24-1, pp. 35-53.

- (ed) (1982): Langage du droit et traduction: essais de jurilinguistique, Montréal, LinguatechConseil de la langue française.

- (1995a): Traduire ou l'art d'interpréter. Fonctions, statut et esthétique de la traduction. Tome 1: Principes, Québec, Presses de l'Université du Québec.

— (1995b): Traduire ou l'art d'interpréter. Langue, droit et société: éléments de jurilinguistique. Tome 2: Application, Québec, Presses de l'Université du Québec.

GiLe, D. (1995): Basic Concepts and Models for Interpreter and Translator Training, Amsterdam/ Philadelphia, John Benjamins.

Groffier, E. (1990): “La langue du droit,” Meta, 35-2, pp. 314-331.

Hammond, M. (1995): "A New Wind of Quality from Europe: Implications of the Court Case Cited by Holz-Mänttäri for the U.S. Translation Industry," in M. Morris (1995), pp. 233245.

Harvey, M. (1997): Les langages juridiques français et anglais: une étude comparative, doctoral thesis, Université Lumière Lyon 2.

- (2000): "A Beginner's Course in Legal Translation: the Case of Culture-bound Terms," in ASTTI/ETI (2000), pp. 357-369.

Jeandidier, W. (2000): "Requiem pour la chambre d'accusation," La Semaine juridique, 46, pp. 2059-2065.

Joliceur, L. (2000): “Traduire Juan Carlos Onetti: entre l'ambiguïté structurelle et l'ambiguïté immédiate," Meta, 45-1, pp. 52-64.

Joseph, J. (1995): “Indeterminacy, Translation and the Law," in M. Morris (1995), pp. 13-36.

Kasirer, N. (2000): "François Gény's libre recherche scientifique as a Guide for Legal Translation," in ASTTI/ETI (2000), pp. 57-85.

Koutsivitis, V. (1988): La traduction juridique. Étude d'un cas: la traduction des textes législatifs des Communautés européennes, et en particulier à partir du français vers le grec, doctoral thesis, Université de la Sorbonne Nouvelle-Paris III.

Lane, A. (1982): "Legal and Administrative Terminology and Translation Problems," in J.-C. GÉmAR (1982), pp. 219-231. 
LaVAult-Olléon, E. (forthcoming): "Variations du rapport auteur-lecteur dans la traduction française de programmes et guides informatiques américains," Le facteur culturel dans la traduction de textes pragmatiques, Cahiers de l'ILCE.

Legault, G. (1979): “Fonctions et structure du langage juridique," Meta, 24-1, pp. 18-25.

Mellinkoff, D. (1963): The Language of the Law, Boston/Toronto, Little, Brown and Co.

Morris, M. (ed) (1995): Translation and the Law, Amsterdam/Philadelphia, John Benjamins.

Morris, R. (1995): "Pragmatism, Precept and Passions: The Attitudes of English-Language Legal Systems to Non-English Speakers," in M. MorRIs (1995), pp. 263-279.

Pelage, J. (2000): "La traductologie face au droit," in ASTTI/ETI (2000), pp. 125-131.

Posner, R. A. (1988): Law and Literature: a Misunderstood Relation, Cambridge (Mass), Harvard University Press.

RaYmond, J. (2000): “The Limits of Logic in Legal Argumentation,” in ASTTI/ETI (2000), pp. 309327.

SAger, J., D. Dungworth \& P. McDonald (1980): English Special Languages. Principles and practice in science and technology, Wiesbaden, Brandstetter.

SArcevic, S. (1997): New Approach to Legal Translation, The Hague/London/Boston, Kluwer Law International.

Sourioux, J.-L. \& P. Lerat (1975): Le langage du droit, Paris, Presses Universitaires de France.

Sparer, M. (1979): "Pour une dimension culturelle de la traduction juridique," Meta, 24-1, pp. 68-94.

— (1988): "L'enseignement de la traduction juridique: une formation technique et universitaire," Meta, 33-2, pp. 320-328.

Weston, M. (1991): An English Reader's Guide to the French Legal System, Oxford, Berg. 